Michał P. Garapich*

\title{
Migracje z Polski do Wielkiej Brytanii: geneza, stan dzisiejszy, wyzwania na przyszłość
}

\begin{abstract}
Migration from Poland to the United Kingdom: The article looks at the selected issues related to the Polish community in the United Kingdom. As a result of the great wave of labour migration following Poland's entry into the EU in 2004, approximately one milion Poles currently live and work in the UK. The author discusses demographics of the Polish community, migration patterns and reasons for this phenomenon, position in the labour market and brexit-related issues.
\end{abstract}
Słowa kluczowe: $\quad$ brexit, migracje, migracje poakcesyjne, Polacy w Wielkiej Brytanii, polscy migranci, Wielka Brytania
Keywords: brexit, migration, post-accession migration, Poles in the UK, Polish migrants, United Kingdom

* Doktor nauk społecznych, pracownik naukowy Uniwersytetu Roehampton i Ośrodka Badań nad Migracjami UW; e-mail: m.garapich@uw.edu.pl • https://orcid.org/ 0000-0003-0248-6780

\section{Wstęp}

Według danych statystycznych w Wielkiej Brytanii mieszka obecnie blisko milion obywateli polskich. W porównaniu z populacją liczącą 75 tys. w 2001 r. nastąpił wzrost ponaddziesięciokrotny. Niniejszy artykuł przedstawia najważniejsze powody tak ogromnego skoku liczebności polskich obywateli w tym kraju, oraz nakreśla ogólną sytuację społeczno-ekonomiczną tej grupy, ze szczególnym uwzględnieniem niepewności prawno-politycznej związanej z decyzją brytyjskiego elektoratu z 2016 r. o wystąpieniu Wielkiej Brytanii z Unii Europejskiej.

W historii polskich migracji 1 maja 2004 r. stanowi cezurę. Tego dnia obywatele polscy uzyskali prawo do swobodnego przemieszczania się i osiedlania w każdym z państw członkowskich Unii Europejskiej, choć w większości państw UE prawo do zatrudnienia obwarowane było okresami przejściowymi, zrezygnowały z nich jedynie trzy - Wielka Brytania, Irlandia i Szwecja. Decyzja ta 
miała istotne konsekwencje. Należy mieć na uwadze, że migracje poakcesyjnie nie tylko są bezprecedensowe, jeśli chodzi o dynamikę i skalę, ale również dlatego, iż zmieniły tradycyjną mapę polskich ścieżek migracyjnych. Wcześniej, zgodnie z tradycją migracji powstałą na przełomie XIX i XX wieku, docelowymi krajami migracji były przede wszystkim Niemcy oraz Stany Zjednoczone. Od 2004 r. jednak na pierwsze miejsce wysunęła się Wielka Brytania. I chociaż dzisiaj, szczególnie w związku z brexitem, skala migracji zmalała, to nadal w tym kraju mieszka jedna z największych na świecie populacji polskich obywateli poza granicami Rzeczpospolitej.

Przyczyny takiej popularności Wysp Brytyjskich od 2004 r. są dość złożone. Bez szczegółowego wdawania się w dywagacje natury teoretycznej i metodologicznej, warto podkreślić przede wszystkim, że przyczyny wyjazdu z Polski i wyboru miejsca docelowego tworzą jeden zestaw czynników decydujący o wielkości polskiej społeczności w tym kraju, drugi zaś tworzą czynniki stojące za pozostaniem tam na stałe bądź na czas dłuższy. Obie grupy czynników bywają powiązane, niemniej na potrzeby przedstawionej analizy należy potraktować je osobno.

\section{Czynniki wypychające i przyciągające}

Jeśli chodzi o przyczyn wyjazdu i wybór miejsca docelowego, to skrótowo ujęli te kwestie autorzy artykułu Migracje z Polski do Zjednoczonego Królestwa po 2004 roku ${ }^{1}$. Czołowi badacze migracji, Marek Okólski i John Salt, odpowiedź na pytanie zawarte w tytule podsumowują: właściwi ludzie, właściwe miejsce, właściwe okoliczności $i^{2}$. Analizując dane statystyczne, podkreślają, że migracje poakcesyjne do Zjednoczonego Królestwa to szczególny przypadek pojawienia się różnorakich determinantów, które zbiegły się w jednym czasie i przestrzeni, dając w efekcie tak ogromny i nagły ruch migracyjny. Demografia i ekonomia wyznaczają makrostrukturalne ramy tych ruchów, gdyż przełom XX i XXI wieku to wchodzenie pokolenia wyżu demograficznego lat 80 . na polski rynek pracy, który wskutek transformacji nie był w stanie go wchłonąć. Ogromne bezrobocie, szczególnie w obszarach wiejskich i w mniejszych miastach, spora liczba absolwentów licznie pojawiających się prywatnych uczelni, a także nadal niski poziom urbanizacji i dostępności tanich mieszkań powodowały, że dla całkiem sporej grupy ludzi wyjazd za granicę stał się naturalnym i często jedynym sposobem zarobkowania. W stymulowaniu wyjazdów grały też rolę czynniki o charakterze kulturowym. Polska jest krajem o zakorzenionej tradycji wyjazdów - dłuższych lub krótszych - zarobkowych, w wyniku których wytworzyła

${ }^{1}$ M. Okólski, J. Salt, Polish emigration to the UK after 2004; why did so many come?, Ośrodek Badań nad Migracjami UW, Central and Eastern European Migration Review, December 2014, s. 1-27.

2 Ibidem, tłum. autora. O ile nie podano inaczej, wszystkie tłumaczenia pochodzą od autora. 
Tabela 1. Pięć najliczniejszych grup zamieszkałych w Wielkiej Brytanii pod względem a) kraju urodzenia; b) obywatelstwa

\begin{tabular}{|l|l|}
\hline \multicolumn{1}{|c|}{ Kraj urodzenia } & \multicolumn{1}{c|}{ Obywatelstwo } \\
\hline 1. Polska $(922000)$ & 1. Polska $(1$ milion) \\
\hline 2. Indie $(829000)$ & 2. Rumunia $(411000)$ \\
\hline 3. Pakistan $(522000)$ & 3. Irlandia $(350000)$ \\
\hline 4. Rumunia $(390000)$ & 4. Indie $(346000)$ \\
\hline 5. Irlandia $(390000)$ & 5. Włochy $(297000)$ \\
\hline
\end{tabular}

Źródło: Office for National Statistics, 2017

się zarówno na szczeblu lokalnym, jak i ogólnym swoista kultura migracji, określająca stosunek do wyjazdów, ich etyczne wartościowanie, znaczenia i strategie życiowe związane z przebywaniem za granicą itp., szczególnie w niektórych regionach Polski, w których ta kultura migracji ma wielopokoleniową tradycję, a o której traktuje pionierska książka w polskich badaniach migracyjnych pod redakcją Marka Okólskiego i Ewy Jaźwińskiej, Ludzie na huśtawce ${ }^{3}$.

Dlatego kolejnym czynnikiem, który odgrywał rolę w dynamicznym procesie wzrostu populacji obywateli polskich w Wielkiej Brytanii, były rozwinięte i działające sieci migracyjne, jakie polska kultura mobilności wytworzyła w ciągu dekad. Maj 2004 r. był datą decydującą, jeśli chodzi o ramy prawne mobilności polskich obywateli, ale nie należy zapominać, że drzwi na brytyjski rynek pracy były, w wyniku zniesienia wiz w roku 1993 czy podpisania umowy stowarzyszeniowej w 1999 r., już od ponad dziesięciu lat nieco uchylone. Okres poprzedzający wejście Polski do UE to okres intensyfikacji wyjazdów - w latach 2002-2003 wjechało do Anglii niemal pół miliona Polaków, z czego można przypuszczać, większość z nich do pracy na czarno (Polacy byli najczęściej zawracaną grupą z granicy brytyjskiej) ${ }^{4}$. Oznacza to, że społeczności polskie w Wielkiej Brytanii nie powstały nagle po roku 2004, ale ich pojawianie się było raczej procesem, który silnie przyspieszył wraz z wejściem do UE. Kolejnymi etapami było zniesienie wiz w 1993 r., przełom 1989 r., stan wojenny w 1981 r. i emigracja solidarnościowa, oraz wcześniejsza polska emigracja pojałtańska. W 1968 r. w wyniku kampanii antysemickiej przyjechało też do Wielkiej Brytanii sporo polskich obywateli. Z kolei w latach 90., szczególnie w drugiej połowie, Wyspy stały się miejscem docelowym emigracji polskich Romów. Rola sieci migracyjnych w tym kontekście jest bardzo ważna, gdyż pozwala uniknąć traktowania powyższych grup jako izolowanych bytów socjologicznych. Emigracja pojałtańska ze swoją

${ }^{3}$ Ludzie na huśtawce. Migracje między peryferiami Polski i Zachodu, red. M. Okólski, E. Jaźwińska, Scholar, Warszawa 2001.

${ }^{4}$ Więcej zob. M. Garapich, Breaking borders, changing structures: transnationalism of migrants from Poland as anti-state resistance, „Social Identities. Journal for the Study of Race, Nation and Culture" 2016, Vol. 22, No 1. 
polityczno-historyczną rolą, szczególnie na poziomie symbolu walki z komunizmem, czy ta z 1968 r. lub późniejsze zachowują swoje cechy specyficzne, ale często zazębiają się na poziomie społecznym, a także poprzez sieci rodzinne bądź zawodowe. Szczególnie widać to w ośrodkach o gęstej strukturze organizacyjnej i dużym kapitale emigracji pojałtańskiej, które jednocześnie stały się miejscem docelowym wyjazdów migrantów poakcesyjnych. Ośrodkami takimi były Londyn czy Manchester, ale także mniejsze, jak Leeds, Bradford czy Southampon.

Zniesienie barier instytucjonalno-prawnych dotyczących mobilności oraz zatrudnienia w 2004 r. miało znaczenie decydujące o liczbie, ale również o strukturze migrantów. Jak zauważają M. Okólski i J. Salt, według danych statystycznych od tego czasu wśród migrantów z Polski do Wielkiej Brytanii zaczyna być coraz więcej osób $\mathrm{z}$ wyższym wykształceniem, co wskazuje na mobilność specjalistów, klasy wyedukowanej w Polsce, która szuka nie tylko lepszych zarobków, ale poszerzenia możliwości kariery zawodowej, co ma szczególną wagę w zawodach związanych z rynkami finansowymi, których londyńskie City nadal pozostaje globalnym centrum ${ }^{5}$. Pamiętać także należy, iż w latach 2004-2008 Wielka Brytania przeżywa okres intensywnego rozwoju i wzrostu gospodarczego przy chronicznym braku rąk do pracy, szczególnie w służbie zdrowia, edukacji, rolnictwie, hotelarstwie i przemyśle spożywczym, a więc czynnikami przyciągającymi polskich migrantów była też wyjątkowa koniunktura na rynku brytyjskim. Co ważne, dla późniejszej mapy docelowych miejsc polskich migracji największy niedobór rąk do pracy pojawia się poza Londynem.

\section{Czynniki skłaniające do osiedlenia}

Z kolei zestaw czynników składający się na proces osiedleńczy jest zupełnie innej natury i na ogólnym poziomie dotyczy przede wszystkim a) lokalnego kontekstu, w jakim znajduje się migrant; b) sytuacji rodzinnej - czy jest sam, czy zostawił rodzinę w kraju i ma zamiar wrócić, czy jest z nią w kraju docelowym, czy też założył ją na emigracji; c) spełnienia aspiracji i oczekiwań, rozwoju zawodowego. Należy przy tym pamiętać, że proces migracyjny rzadko jest jasno przez ludzi zaplanowany i dość częstą strategią stosowaną przez migrantów jest otwartość, decyzyjna niepewność, „intencjonalna nieprzewidywalność”6, czyli niedeterminowanie swoich planów i otwarcie na możliwości, jakie mogą się pojawić, co w przypadku tak wysoko rozwiniętej gospodarki jak brytyjska jest działaniem jak najbardziej racjonalnym.

W przypadku migracji z Polski do Wielkiej Brytanii można stwierdzić, że w początkowym okresie krótkoterminowe plany bądź otwartość możliwości

${ }_{5}$ M. Okólski, J. Salt, Polish emigration to the UK after 2004, op. cit.

${ }^{6}$ J. Eade, S. Drinkwater, M. Garapich, Class and Ethnicity. Polish Migrants in London, University of Surrey, Guilford 2006. 
migracyjnych dominowały. Pierwsze fale migracyjne na początku XXI wieku to przeważnie ludzie młodzi, przed ukończeniem 30. roku życia. Niemniej już kilka lat po 2004 r. badacze zidentyfikowali symptomy transformacji migracji krótkoterminowej w osiedleńczą, przynajmniej części z nich. Jednym z pierwszych sygnałów była skala urodzeń dzieci, których matki są Polkami, co skłoniło ekonomistkę i specjalistkę od badań migracji Krystynę Iglicką do komentarza, że Polki głosują brzuchami ${ }^{7}$. Rzeczywiście, w dość szybkim tempie Polki wyszły na prowadzenie w rankingu niebrytyjskich kobiet rodzących dzieci. W przywoływanym już artykule M. Okólskiego i J. Salta również znaleźć można sygnały wskazujące na to, że polscy migranci zaczynają bardziej myśleć o osiedleniu się na stałe, pod postacią wyraźnej mobilności społecznej i awansu, zwłaszcza jednostek wysoko wyspecjalizowanych. Inną wskazówką jest też malejąca od kilku lat skala przepływów finansowych do Polski

Badania migracyjne obfitują w opracowania naukowe dotyczące przyczyn, dla których obywatele polscy decydują się na pozostanie w Wielkiej Brytanii (obszerne opracowanie stworzył Komitet Badań nad Migracjami PAN w 2014 r.) $)^{9}$. Ponieważ decyzje te, dotyczące często rodzin, są niezmiernie skomplikowane i wyjątkowe dla danego przypadku, trudno jest skwantyfikować odpowiedź na pytanie, dlaczego Polacy zostają w Wielkiej Brytanii. Dlatego badania naukowe eksplorujące ten temat są przeważnie prowadzone za pomocą metod jakościowych i etnograficznych, w których chodzi o uchwycenie całego kontekstu życiowego badanych, znaczenia, jakie nadają określonym indywidualnym hierarchiom wartości, czy po prostu refleksji dotyczącej własnej biografii. W opracowaniach dotykających tego tematu dominuje perspektywa porównawcza, jaką stosują badane jednostki, odnosząc ich doświadczenie w Polsce do doświadczenia w Wielkiej Brytanii. W obszarze łatwości prowadzenia małych przedsiębiorstw, laskawości fiskusa brytyjskiego wobec samozatrudnionych, jeśli chodzi o płacenie składek, relacji państwo-obywatel, jakości służby zdrowia, edukacji dzieci oraz możliwości na rynku pracy, badani przeważnie podkreślają wyższość systemu brytyjskiego nad polskim ${ }^{10}$. W publikacjach przewija się uogólniające stwierdzenie wielu polskich migrantów dotyczące „normalności” życia w Wielkiej Brytanii ${ }^{11}$, ich refleksji, iż dopiero tam przekonali się, jak

7 Https://wiadomosci.onet.pl/tylko-w-onecie/prof-iglicka-okolska-dla-polskich-emigrantow-win-dla-polski-straszliwa-strata/t9d0t [dostęp: 10 grudnia 2019 r.].

8 M. Okólski, J. Salt, Polish emigration to the UK after 2004, op. cit.

9 Komitet Badań nad Migracjami PAN, Społeczne skutki poakcesyjnych migracji ludności Polski, PAN, Warszawa 2014.

10 I. Grabowska, M.P. Garapich, E. Jazwinska, A. Radziwinowicz, Migrants as Agents of Change. Social remittances in an enlarged European Union, Palgrave Macmillan, London 2017.

${ }_{11}$ M. Rabikowska, Negotiation of normality and identity among migrants from Eastern Europe to the United Kingdom after 2004, „Social Identities. Journal for the Study of Race, Nation and Culture" 2010, Vol. 16, No 3, s. 285-296. 
pewne kwestie powinny zostać urządzone - dotyczące pracy, polityki, relacji sąsiedzkich, tolerancji czy zasad kurtuazji ${ }^{12}$. Oczywiście nie brak i ocen negatywnych, niemniej zazwyczaj pytani o uzasadnienie wyboru życia w Wielkiej Brytanii polscy obywatele odnoszą się do wspomnianej wyżej skali porównawczej z Polską na przeciwległym końcu. To porównanie dotyczyć może także bardziej "miękkich” kwestii związanych z większą tolerancją społeczeństwa brytyjskiego wobec mniejszości, mniejszą rolą Kościoła w życiu społecznym czy polityką prowadzoną na bardziej koncyliacyjnym poziomie.

\section{Obraz polskich społeczności w Wielkiej Brytanii}

Należy podkreślić, że niniejsze opracowanie jest raczej zarysem pewnych aspektów życia obywateli polskich w Wielkiej Brytanii i obraz tu przedstawiony jest pewnym kompromisem między detalem etnograficznym a ogólną syntezą tego, co wiemy z opracowań nauk społecznych, raportów różnych organizacji oraz prasy. Dlatego do zasygnalizowanego w podtytule zagadnienia istnienia jednej polskiej społeczności zamieszkującej Wyspy Brytyjskie trzeba podchodzić sceptycznie. Wedle doświadczenia badawczego autora niniejszego artykułu traktowanie ujednolicające tę grupę pod terminem „społeczność” jest bardziej mylące niż informujące i fałszuje rzeczywistość empiryczną na rzecz zbytniej generalizacji. Bardziej pomocne jest mówienie o społecznościach polskich w liczbie mnogiej, grupie o niezmiernie heterogenicznej strukturze wewnętrznej, zróżnicowanej zarówno z uwagi na miejsce pochodzenia w Polsce, klasę społeczną, wykonywany zawód, jak i przyczyn zewnętrznych, czyli gdzie mieszkają w Wielkiej Brytanii.

Ten ostatni czynnik jest istotny, gdyż w odróżnieniu od poprzednich fal migracji z Polski, a także z innych krajów, migracje poakcesyjne „rozlały się” po całym państwie i dzisiaj spotkać można obywateli polskich zamieszkałych w niemal każdym zakątku Anglii, Szkocji i Walii (rysunek 1). Oznacza to jednocześnie, że wewnętrzne zróżnicowanie Polaków zostaje dodatkowo spotęgowane przez specyfikę lokalnego kontekstu. Zjednoczone Królestwo to państwo o strukturze federacyjnej, złożone z czterech krajów, różniących się historią, kulturą, czasem językiem (a na pewno akcentem), niekiedy systemem prawnym (np. między Anglią a Szkocją) itd. Społeczność Polaków w Belfaście na przykład różni się co do stopnia zasiedzenia czy wykonywanej pracy, a także miejscem w lokalnej strukturze społecznej, szczególnie ze względu na wyznanie, co w kontekście konfliktu

${ }_{12}$ I. Grabowska, M.P. Garapich, E. Jazwinska, A. Radziwinowicz, Migrants as Agents of Change, op. cit.; M. Rabikowska, K. Burrell, The material worlds of recent Polish migrants: Transnationalism, Food, Shops and Home [w:] Polish Migration to the UK in the 'New' European Union: After 2004, ed. K. Burrell, Ashgate, Aldershot 2009, s. 211-232; A. White, Polish families and Migration in Poland since EU Accession, Policy Press, Bristol 2011. 


\section{Rysunek 1. Rozmieszczenie obywateli polskich w Anglii i Walii oraz Londynie, z udzia- łem procentowym w ogólnej populacji w poszczególnych okręgach wyborczych}

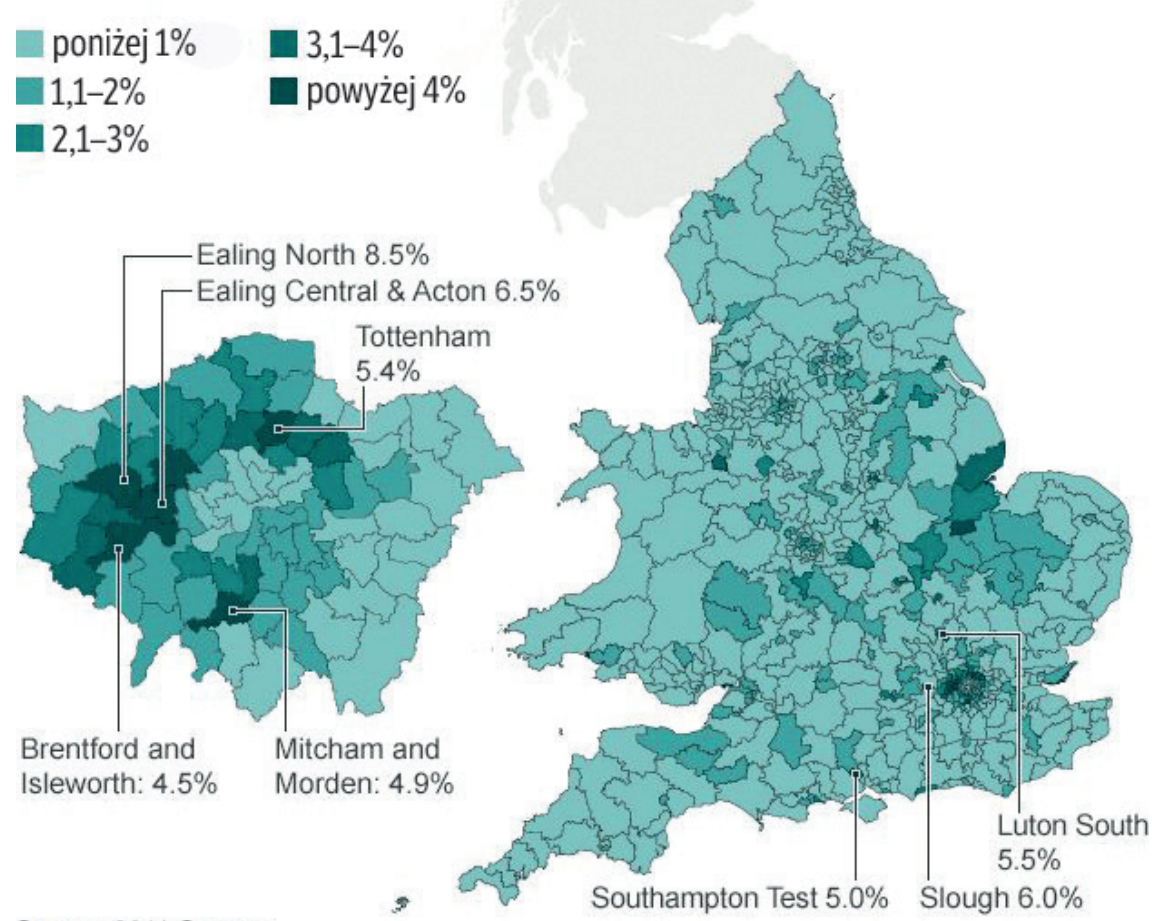

Source: 2011 Census

między katolikami a protestantami jest bardzo ważne ${ }^{13}$. Nie mają takich problemów Polacy w Peterborough na północ od Londynu, ale z uwagi na lokalny rynek pracy jest to społeczność w przeważającej mierze pracująca w rolnictwie, z dużą liczbą osób zatrudnionych sezonowo. W mniejszych miastach Anglii, szczególnie uboższej jej części, Polacy dużo częściej spotykają się z niechęcią lub ksenofobią, co jest o wiele mniej spotykane w kosmopolitycznym Londynie.

Jeśli chodzi o aktywność ekonomiczną, to można zaryzykować uogólnienie, że społeczności polskie cechują się dużym stopniem integracji w różne segmenty gospodarki brytyjskiej: obywateli polskich charakteryzuje duża skala obecności na rynku, zarówno na etacie, jak i w formie samozatrudnienia. Można stwierdzić, że Polacy są obecni na każdym szczeblu, najliczniej reprezentowani w zawodach fizycznych, takich jak usługi remontowe, przemysł przetwórczy, rolnictwo, usługi czy hotelarstwo. Na podstawie brytyjskiego sondażu aktywno-

${ }_{13}$ M. Kempny, Polish Migrants in Belfast: border crossing and identity construction, Cambridge Scholars Press, Newcastle upon Tyne 2010. 
ści na rynku pracy (Labour Force Survey, LFS) z lat 2016/2017 (dane dostępne odnośnie do polskiej populacji) obraz obywateli polskich pod względem aktywności ekonomicznej przedstawia się następująco (dane na podstawie LFS i Office for National Statistics) ${ }^{14}$ :

- Polacy są bardzo aktywni ekonomicznie, $85,1 \%$ z nich pracuje zawodowo (przy 74,6\% aktywności obywateli brytyjskich, 83,4\% obywateli innych państw akcesyjnych i 79,9\% obywateli państw „starej Unii”, tzw. UE-15). Jedynie 3,9\% z nich nie pracuje, przy 4,3\% stopie bezrobocia wśród obywateli brytyjskich.

- Jednocześnie większość pracuje w zawodach niewymagajacych wysokich kwalifikacji, fizycznie, w usługach, w małych firmach. $26,6 \%$ pracuje w przetwórstwie i produkcji (9,4\% obywateli UK, $8 \%$ obywateli UE-15), $7,2 \% \mathrm{w}$ budownictwie (7,6\% obywateli UK, $4,9 \%$ obywateli UE-15), $35,5 \% \mathrm{w}$ usługach cateringowym, hotelarstwie, sprzedaży i transporcie (22,7\% obywateli UK, $22 \%$ obywateli UE-15). W zawodach wysoko wyspecjalizowanych, wśród profesjonalistów, w nauce czy administracji Polaków pracuje niemal tyle samo co obywateli Wielkiej Brytanii (odpowiednio $11 \%$ i 11,3\%), ale mniej niż obywateli „starej UE” (14,8\%). Jeśli chodzi o administrację publiczną, sektor państwowy, służbę zdrowia czy edukację, to Polaków pracuje o wiele mniej niż obywateli brytyjskich (9,6\% przy $31,9 \%)$ czy obywateli UE-15 (30\%).

- Polacy przodują też jeśli chodzi o samozatrudnienie, szczególnie w Londynie, co odzwierciedla dużą obecność polskich firm budowlano-remontowych (dużych i małych) w stolicy. Niemal 38\% pracujących w Londynie Polaków to osoby samozatrudnione (przy 16,4\% obywateli brytyjskich). W całym Zjednoczonym Królestwie odsetek ten wynosi 13,7\%, niemal tyle samo co obywateli brytyjskich (14\%) i obywateli UE-15 (17,4\%).

- Na tle innych narodowości Polacy gorzej radzą sobie z językiem angielskim. Sześć procent deklaruje, że angielski jest ich głównym językiem (20\% z innych nowych państw członkowskich i 55,7\% obywateli „starej UE” złożyło taką deklarację), a 26,7\% oświadczyło, że mówi słabo albo w ogóle (w innych grupach wielkości te rozkładały się odpowiednio 17,7\% i 2,8\%).

\section{Zaangażowanie społeczne i polityczne oraz zaplecze instytucjonalne}

Zróżnicowanie w obrębie polskich społeczności przejawia się bardzo silnie w kwestii partycypacji społecznej i politycznej - czyli uczestnictwie w różnego

${ }^{14}$ Https://www.ons.gov.uk/releases/uklabourmarketstatisticsdec2016; cyt. za: S. Drinkwater, Migration and integration into the UK Labour Market, IMISCOE Spring Conference Warsaw, March 2018. 
rodzaju organizacjach społeczeństwa obywatelskiego, kościołach, związkach zawodowych czy partiach politycznych. Wydaje się, że w Wielkiej Brytanii zachodzi podobny proces co $\mathrm{w}$ innych krajach Europy nie tylko $\mathrm{z}$ dużą liczbą polskich migrantów, ale obejmujący także inne mniejszości. Wiąże się to ze zidentyfikowanym przez badaczy procesem dywersyfikacji stowarzyszeniowości imigranckiej i odchodzeniu starego modelu w przeszłość. Jak zauważają socjologowie, skala partycypacji w tradycyjnych stowarzyszeniach polonijnych już od dawna maleje. Michał Nowosielski, pracownik naukowy Ośrodka Badań nad Migracjami UW, wskazuje na przykład, że jedynie mniejszość Polaków działa w organizacjach polskich, w skali Europy jest to około 12\% Polaków mieszkających za granicą ${ }^{15}$.

Powyższe nie oznacza jednak, że Polacy się nie angażują, ale że raczej nie mówią jednym głosem lub po prostu tradycyjnych polskich organizacji już nie potrzebują. Według badania Instytutu Spraw Publicznych przeprowadzonego w 2013 r. na temat partycypacji politycznej i społecznej wśród Polaków w Wielkiej Brytanii ${ }^{16}$, mimo że liderzy narzekają na brak zaangażowania i jednolitej reprezentacji Polaków tym kraju, jednocześnie nie są w stanie zidentyfikować podstaw, aby taki głos był politycznie potrzebny i uzasadniony, ponieważ brak jest jednej zgodnej płaszczyzny porozumienia. Jako mniejszość Polacy nie są jaskrawo dyskryminowani przez instytucje państwowe, cieszą się też prawami niemal na równi z Brytyjczykami - chociaż to się może w związku z brexitem zmienić - nie ma więc jednej kwestii jednoczącej Polaków. Badanie wykazało, że obywatele polscy są niezmiernie zróżnicowani pod względem politycznym i światopoglądowym, co jest dodatkowo wzmacniane przez kontekst lokalny, gdyż wstępują także do organizacji brytyjskich zajmujących się kwestiami niekoniecznie związanymi z polską tożsamością - takimi jak sprawy związane z ochroną środowiska, prawami człowieka czy konsumenta, ruchami artystycznymi. Badanie wykazało, że Polacy obecni są we wszystkich ugrupowaniach o charakterze politycznym - włącznie z nagłośnioną ostatnio przez media brytyjskie sprawą polskich organizacji skrajnie prawicowych lub faszystowskich, niekiedy nawiązujących stosunki z podobnymi organizacjami brytyjskimi ${ }^{17}$.

Polskie społeczności wydają się w Wielkiej Brytanii ulegać podobnemu procesowi co inne grupy imigrantów, od tradycyjnych stowarzyszeń, mających za zadanie podtrzymanie tożsamości etnicznej i językowej czy działalność stricte pomocową, przechodzą do bardziej płynnych, horyzontalnych sieci zainteresowań, gdzie etniczna czy narodowa wspólnota nie jest dominantą jednoczącą ludzi, ale są nimi wyznaczniki klasowe, styl życia, wzory konsumpcji. Co także

15 M. Nowosielski, Zaangażowanie Polaków mieszkających za granica w działalność organiizacji polonijnych, „Kultura i Edukacja” 2014, nr 1(101), s. 152.

${ }^{16}$ Nic o nas bez nas. Partycypacja obywatelska Polaków w Wielkiej Brytanii, red. J. Kucharczyk, Instytut Spraw Publicznych, Warszawa 2013.

17 Https://www.bbc.co.uk/news/uk-44601218 [dostęp: 20 listopada 2019 r.]. 
wykazało badanie Instytutu Spraw Publicznych, Polacy preferują nieformalny sposób stowarzyszania się ${ }^{18}$. Proces przemiany funkcji tradycyjnych stowarzyszeń wynika nie tylko z rozwoju nowoczesnych środków komunikacji i partycypacji społecznej, ale także $\mathrm{z}$ formalnoprawnego statusu polskich obywateli pod względem dostępu do rynku pracy, osłony socjalnej i praw obywatelskich. Badania, takie jak M. Nowosielskiego czy Instytutu Spraw Publicznych pokazują, że wraz ze zrównaniem prawnym polskich migrantów w obrębie rynków europejskich zapotrzebowanie na formalne tradycyjne stowarzyszenia etniczne zmalało. Ewidentnie widać to w przypadku polskiego Kościoła katolickiego, który niegdyś był centrum życia społecznego migrantów, służącym jednocześnie za miejsce wymiany informacji, spotkań, nieformalny rynek pracy i usług. Jak wskazują opracowania, obecnie rola tej instytucji się zmienia, a według opracowań w Anglii jedyne 8\% polskich emigrantów uczęszcza regularnie do kościoła, co zdaniem niektórych i tak jest wielkością zawyżoną ${ }^{19}$. Podczas pobytu w Wielkiej Brytanii wielu Polaków dystansuje się od katolicyzmu i życia skupionego wokół Kościoła. Przyczyny tej sytuacji są związane z różnicami kulturowymi między nowymi i starymi grupami polskiej migracji, z młodym wiekiem imigrantów i z koncentracją głównie na pracy. Badania przeprowadzone w Aberdeen wykazały, że polscy księża, których wielu przyjechało do Wielkiej Brytanii w związku ze zwiększonym zapotrzebowaniem na msze w języku polskim, mają tendencję do konserwowania i wzmacniania polskiego katolicyzmu, co może dodatkowo zniechęcać polskich migrantów. Bagaż kulturowy, ale również odmienne postrzeganie samej religii katolickiej przez polskich księży bywa również negatywnie odbierane na poziomie lokalnym przez miejscowych katolików, np. szkockich ${ }^{20}$. Wzmacnianie polskiego katolicyzmu przez język celebrowania nabożeństw i trzymanie się typowych polskich obrzędów powoduje w konsekwencji powstawanie tak zwanych równoległych wspólnot religijnych i nie sprzyja integracji ${ }^{21}$. Jak wskazuje Joanna Krotofil, powoduje to, że wielu młodych albo odwraca się od Kościoła, albo szuka połączenia katolicyzmu z praktykami znanymi bardziej z ewangelickich kościołów, zwłaszcza charyzmatycznych ${ }^{22}$.

${ }_{18}$ P. Pustułka, Pomijani multi uczestnicy. Polacy winicjatywach nieformalnych w Wielkiej Brytanii [w:] Nic o nas bez nas. Partycypacja obywatelska Polaków w Wielkiej Brytanii, red. J. Kucharczyk, Instytut Spraw Publicznych, Warszawa 2013, s. 105-132; M. Irek, Travelling with the Argonauts: Informal Networks Seen without a Vertical Lens Berghahn, Oxford 2018.

${ }_{19}$ M. Lisak, Religijność instytucjonalna jako czynnik adaptacji polskich imigrantów w Irlandii, „Studia Migracyjne - Przegląd Polonijny” 2015, nr 2(156), s. 107.

${ }_{20}$ H. Grzymała-Moszczyńska, D. Hay, J. Krotofil, Between universalism and ethnic particularism: Polish migrants to the United Kingdom; perspective from the psychology of religion, „Studia Migracyjne - Przegląd Polonijny” 2011, nr 1(37), s. 223-236.

${ }^{21}$ Ibidem.

22 J. Krotofil, Religia w procesie kształtowania tożsamości wśród polskich migrantów w Wielkiej Brytanii, Nomos, Kraków 2013. 
Obraz jeszcze bardziej komplikuje fakt, że od 2004 r. Wielka Brytania, a szczególnie Londyn, stała się centrum polskojęzycznych zborów Świadków Jehowy ${ }^{23}$, a wspomniana już J. Krotofil dokumentuje i analizuje rosnącą liczbę polskich konwertytów na islam ${ }^{24}$. Podobnie jak partycypacja polityczna, heterogeniczność życia religijnego Polaków na Wyspach pokazuje, jakim dynamicznym procesom różnicującym jest poddana ta populacja.

Niemałym zainteresowaniem wśród Polaków cieszą się związki zawodowe. Jak wynika z innej analizy Instytutu Spraw Publicznych ${ }^{25}$, niemal 8\% polskich pracowników należy do brytyjskich związków. To mało, zważywszy, że stopień uzwiązkowienia w Wielkiej Brytanii wynosi 25\%, ale biorąc pod uwagę dane z Polski - 11\% pracujących w Polsce należy do związków - już nie. Według badań M. Nowosielskiego niewiele więcej Polaków angażuje się w Wielkiej Brytanii w życie organizacji polonijnych $-9,4 \%{ }^{26}$. Konkluzja z dotychczasowych badań na ten temat jest taka, że organizacje polonijne to po prostu jedna z wielu możliwych form stowarzyszania się - nie bardziej naturalna ani popularna niż inne, akcentujące inne wymiary tożsamości, zainteresowań czy potrzeb społeczno-ekonomicznych.

Opisane zjawiska są zgodne ze zmianami społecznymi wywołanymi przez swobodny dostęp do rynku pracy i uprawnień społecznych i obywatelskich państwa opiekuńczego, gdzie kluczową kwestią jest sprawdzona i kompetentna informacja i porada. W przeszłości, kiedy wśród polskich imigrantów dominował nieformalny rynek pracy i usług, obieg informacji wokół Kościoła lub polonijnego stowarzyszenia wyczerpywał potrzeby. Kiedy migrant musi poznać całą gamę uprawnień, przywilejów i obowiązków, jaka mu przysługuje w zależności od sektora na wysoko rozwiniętym kapitalistycznym rynku pracy, rośnie popyt na fachową usługę poradniczą. To zapewne stąd migracje poakcesyjne, a szczególnie w Wielkiej Brytanii wygenerowały specyficzny „przemysł migracyjny" ${ }^{27}$ w postaci ogromnej i wyrafinowanej tkanki handlowo-usługowej dla Polaków. W każdym najmniejszym skupisku polskim można znaleźć polski sklep, po-

${ }^{23}$ K. Fiałkowska, M.P. Garapich, E. Mirga-Wójtowicz, Roma Migrations - Transnationalism and Identity in Anthropological Perspective, „Ethnologia Polona” 2019, Vol. 40, s. 247-276.

${ }^{24} \mathrm{~J}$. Krotofil, 'If I am to be a Muslim, I have to be a good one'. Polish migrant women embracing Islam and reconstructing identity in dialogue with self and others [w]: Muslims in Poland and Eastern Europe. Widening the European Discourse on Islam, ed. K. Górak-Sosnowska, University of Warsaw, Warszawa 2011.

25 R. Dunin-Wąsowicz, M. Garapich, Zaangażowanie Polaków w brytyjskie związki zawodowe [w]: Solidarność $w$ działaniu. Prawa pracownicze, udział $w$ dialogu społecznym oraz uzwiązkowienie Polaków w Wielkiej Brytanii, red. D. Potkańska, D. Owczarek, Instytut Spraw Publicznych, Warszawa 2015.

${ }_{26}$ M. Nowosielski, Zaangażowanie Polaków mieszkających za granica, op. cit.

27 M. Garapich, The Migration Industry and Civil Society: Polish Immigrants in the United Kingdom Before and After EU Enlargement, „Journal of Ethnic and Migration Studies” 2008, No 34(5), s. 735-752. 
radnictwo podatkowe, portal informacyjny, a w większych ośrodkach, takich jak Londyn, Manchester, Bristol czy Liverpool, polska oferta skierowana do migrantów obejmuje firmy budowlane, kliniki medyczne, lekarzy, przedszkola, porady prawne, fryzjerów, restauracje, gazety, rozgłośnie radiowe, pośrednictwa pracy, firmy organizujące koncerty, ligi sportowe itd. W większości miejscowości istnieją oczywiście organizacje społeczne skupiające Polaków, ale stanowią one raczej dodatek do opisanej infrastruktury etniczno-usługowej.

Osobną instytucją, która w Wielkiej Brytanii zdecydowanie na nowej fali migracji zyskała, jeśli chodzi o liczby, to tzw. szkoły sobotnie, placówki edukacyjne dla dzieci w wieku do 16 lat, w których uczy się języka polskiego i historii. $\mathrm{W}$ odróżnieniu od tradycyjnych organizacji, $\mathrm{w}$ ostatnim dziesięcioleciu przeżywają one ogromny wzrost, co jest skutkiem dużej dzietności rodzin polskich. Większość, ale nie wszystkie, szkół jest zarejestrowana w Polskiej Macierzy Szkolnej - założonej jeszcze przez emigrację powojenną organizacji parasolowej czuwającej nad jakością nauczania języka polskiego i historii. Według szacunków tej organizacji w 2012 r. na Wyspach było tych szkół 118.

Nie należy zapominać, że założona i utrzymywana przez emigrację powojenną i ich spadkobierców sieć instytucjonalna nadal jest dość aktywna i żywa, a wiele ośrodków emigracyjnych, którym z końcem lat 90. przepowiadano upadek i zamknięcie, zostało ożywione, zarówno jeśli chodzi o personel, jak i ofertę programową. Proces ten nie odbywa się bez tarći typowych dla każdej diaspory konfliktów na linii pokoleniowej, ideologicznej czy politycznej. Wiele z tych instytucji prowadzonych jest zarówno przez Polaków już w Wielkiej Brytanii urodzonych, jak i tych niedawno przybyłych, stąd można wnosić, że różnice są niwelowane na rzecz wspólnej pracy.

\section{Brexit - wyzwania na przyszłość}

Decyzja brytyjskiego elektoratu o wyjściu Zjednoczonego Królestwa z Unii Europejskiej (52\% za, 48\% przeciwko) podjęta w referendum 23 czerwca 2016 r. stała się jednym z głównych politycznych wyzwań tego państwa ostatnich dekad, a nawet, jak twierdzą niektórzy, od czasów drugiej wojny światowej. Tuż po referendum w niektórych miastach Anglii notowano przypadki ksenofobii i ataków rasistowskich, również wymierzonych w Polaków. Od tego czasu dochodzi do sporadycznych zachowań rasistowskich, ale nie mają one charakteru masowego. Obecnie trudno jest przewidzieć, czy po wyjściu Zjednoczonego Królestwa z UE tendencje te się nasilą. Z pewnością należy zwracać szczególną uwagę na sytuację w tej kwestii.

Sprawą zajmującą negocjatorów i jednocześnie dotykającą milionów ludzi jest status imigracyjny obywateli państw UE. Ich prawa (liczbę w Wielkiej Brytanii szacuje się na około 3,7 mln) po wyjściu z UE (co nastąpi 31 stycznia 2020 r.) są jedną z wielu kwestii, które ulegną zmianie, niemniej należy zauważyć, że 
była ona wysoko na liście priorytetów obu stron od samego początku negocjacji o warunkach wystąpienia Zjednoczonego Królestwa z Unii Europejskiej. Chodziło o gwarancję dla milionów ludzi - zarówno obywateli UE w Wielkiej Brytanii, jak i Brytyjczyków zamieszkałych w państwach Unii - że ich prawa nabyte nie zostaną im odebrane. $\mathrm{Z}$ obu stron padały więc deklaracje uspokajające i zapewniające, iż wszelkie prawa będą respektowane.

Niemniej głównym wyzwaniem dla władz brytyjskich, przygotowujących się do wyjścia z UE, było zakończenie wolnego przepływu siły roboczej w konkretnym momencie, a co za tym idzie stworzenie cezury czasowej, oddzielającej moment nabycia praw przez migrujących obywateli UE. Logicznym wyjściem z tej sytuacji było więc stworzenie systemu ewidencji obywateli UE zamieszkałych na stałe w Wielkiej Brytanii. Było to wyzwanie bez precedensu, ponieważ Zjednoczone Królestwo nie prowadzi spisu ludności ani nie ma ekwiwalentu systemu PESEL, nie wiadomo więc do końca, o ilu ludziach mowa. Wprowadzony w marcu 2019 r. European Settlement Scheme $e^{28}$ jest systemem rejestracji obywateli UE, którzy zamierzają potwierdzić swój status, a co za tym idzie przysługujące im prawa po wyjściu Wielkiej Brytanii z UE.

System stosuje dość prostą procedurę korzystającą z internetu i telefonu komórkowego, i według sprawozdań do października 2019 r. skorzystało z niego, a więc potwierdziło swoje prawa, ponad dwa miliony osób, z czego 370 tys. obywateli polskich. European Settlement Scheme jednak, jak każda rejestracja populacji imigranckiej ma swoje wady, przede wszystkim selekcję dostępności i aplikacji pod względem wykształcenia, znajomości technologii, kompetencji językowych itd. Doświadczenie rejestracji podobnych populacji uczy, że poza nawias formalnych kategorii wypadają jednostki uboższe, pozbawione kompetencji, w różny sposób wykluczone, a każdy system formalizacji statusu imigrantów produkuje jako efekt uboczny imigrantów o nieuregulowanym statusie, i nic nie wskazuje, aby w tym wypadku było inaczej. Zwracają szczególnie na to uwagę organizacje chroniące prawa mniejszości czy osób na granicy ubóstwa. $\mathrm{Na}$ przykład parasolowa organizacja zrzeszająca Romów w Londynie, Roma Support Group od dawna ostrzega, że brexit nieproporcjonalnie uderzy w romską mniejszość ${ }^{29}$, z uwagi na słabą znajomość prawa, języka, a także obaw populacji romskiej przed dyskryminacją przez państwo. Podobnie organizacje zajmujące się ludźmi bezdomnymi stoją na stanowisku, że nowe regulacje wytworzą całą klasę ludzi „niewidzialnych” prawnie i instytucjonalnie ${ }^{30}$.

Na niekorzyść państwa brytyjskiego w tej kwestii świadczy tzw. skandal Windrush, który wybuchł w 2016 r. jako konsekwencja walki z łamaniem przepisów

${ }^{28} \mathrm{Https} / /$ www.gov.uk/settled-status-eu-citizens-families.

${ }^{29}$ Https://www.romasupportgroup.org.uk/roma-and-brexit.html.

${ }^{30}$ B. Drozdowicz, The impact of brexit on inclusion and integration of Poles in the UK [w]: Brexit and Polonia: Challenges facing the Polish Community during the process of Britain leaving the European Union, ed. M. Fleming, PUNO PRESS, 2018. 
imigracyjnych (tzw. hostile environment) wprowadzonej przez ówczesną szefową Home Office, Theresę May. W ramach tej polityki instytucje, takie jak szkoły, służba zdrowia, uniwersytety, pracodawcy, agenci nieruchomości, zobowiązane zostały do sprawdzania statusu imigracyjnego klientów, co doprowadziło do sporej liczby opisywanych przez media rażących przypadków łamania praw człowieka. Najczęściej dotyczyły one ludzi z tzw. pokolenia Windrush, przybyłych do Wielkiej Brytanii z Karaibów w latach 60. Konsekwencją tej nowej polityki były sytuacje, w których nakaz opuszczenia kraju dostawała osoba zamieszkała w Wielkiej Brytanii od 50 lat ${ }^{31}$. Krytycy systemu ewidencji obywateli UE wskazują, że to samo może się stać z obywatelami europejskimi.

Należy też zauważyć, że w ramach polityki T. May deportowano również obywateli europejskich, także Polaków już mniej więcej od 2013 r. Dla zawyżenia liczb deportowanych brytyjskie służby imigracyjne na cel brały populacje bezdomnych, w tym Polaków, których umieszczano w zamkniętych ośrodkach. O praktyce zrobiło się głośno po samobójstwie obywatela polskiego Marcina Gwoździńskiego, który został umieszczony w ośrodku tylko dlatego, że spał w londyńskim parku w namiocie ${ }^{32}$. Praktyka deportowania bezdomnych obywateli UE została zaskarżona przez organizację chroniącą prawa człowieka North East London Migrant Action ${ }^{33}$, a w grudniu 2017 r. sąd brytyjski uznał ją za niezgodną z prawem. Teoretycznie brytyjskie służby wstrzymały tę politykę, w praktyce jednak nadal zdarzają się przypadki deportacji obywateli UE.

Powyższa praktyka jest pewną wskazówką możliwych działań brytyjskich władz po wyjściu z Unii Europejskiej, a zwłaszcza po upływie okresu obowiązkowej rejestracji w European Settlement Scheme (na razie ustaloną na 31 grudnia 2020 r.). Jednocześnie pozwala wyobrazić sobie, jak brexit wpłynie na wspomnianą wyżej heterogeniczność polskich społeczności. Ponieważ wszystko wskazuje na to, że Wielka Brytania pozostanie atrakcyjnym celem migracji, zamknięcie rynku pracy tego państwa oznaczać będzie wytworzenie się szarej strefy, nieformalnego rynku pracy. Funkcjonował on przez wiele lat przed akcesją Polski do UE, i jak wskazano wyżej, stanowił pewien grunt, z którego korzystali późniejsi migranci poakcesyjni. Nie ma powodu więc, aby nie pojawił się znowu. Konsekwencją tego będzie silne rozwarstwienie polskich społeczności już nie tylko z uwagi na pochodzenie klasowe, miejsce zamieszkania, status społeczny czy długość pobytu, ale też jego legalność. Istnienie tego „podziemia migracyjnego" w ramach jednej grupy etnicznej będzie z pewnością sprzyjać pojawieniu się zorganizowanej przestępczości, licznych patologii typu współczesne

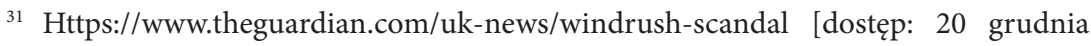
2019 r.].

${ }^{32}$ Https://www.theguardian.com/uk-news/2017/dec/03/marcin-gwozdzinski-immigration-centre-detention-death [dostęp: 20 grudnia 2019 r.].

${ }^{33}$ Https://www.theguardian.com/uk-news/2017/dec/14/home-office-policy-deport-eu-rough-sleepers-ruled-unlawful [dostęp: 20 grudnia 2019 r.]. 
niewolnictwo, handel ludźmi, przemyt itd. Inną przesłanką przemawiającą za pojawieniem się polskiego podziemia imigranckiego w związku z brexitem jest fakt, że nowe przepisy migracyjne, jakie zamierza wprowadzić rząd brytyjski, będą na szczególnych prawach traktować wysokiej klasy specjalistów kosztem średnio wykształconych pracowników fizycznych. Nowe przepisy nie będą też pozwalać angażować się $\mathrm{w}$ tak powszechne wśród polskich migrantów migracje wahadłowe, gdyż wzrosną koszty przekraczania granicy, wymogi formalne, ryzyko deportacji i straty inwestycji w migrację. Postawieni przed wyborem, czy wracać, czy zostać, migranci najczęściej będą wybierać to drugie, zwiększając szeregi migrantów o nieuregulowanym statusie.

\section{Wnioski}

Niniejsze opracowanie miało na celu zarysowanie obrazu społeczności polskich w Wielkiej Brytanii, nie roszcząc sobie pretensji do wyczerpania tego zagadnienia. W ostatnich latach powstały setki opracowań, artykułów naukowych, raportów i książek na temat migracji do tego kraju i jest to niezwykle bogata i dynamiczna sfera badawcza ${ }^{34}$. Dodatkowe zmiany polityczno-instytucjonalne w tym kraju oraz ciągłe zmiany demograficzno-kulturowe powodują, że nie da się stworzyć statycznego obrazu polskich społeczności w Wielkiej Brytanii. Najważniejsze konkluzje z niniejszego artykułu dotyczą heterogeniczności polskich skupisk. Należy również pamiętać, że rośnie drugie i trzecie pokolenie polskich Brytyjczyków, którzy dodatkowo mogą mieć inną afiliację kulturowo-religijno-etniczną, co jeszcze silniej skomplikuje obraz polskich społeczności. Długofalowe zmiany oznaczać będą większą pluralizację i integrację w społeczeństwo brytyjskie Polaków i ich potomków. Pamiętajmy, że polska populacja w Wielkiej Brytanii już jest zróżnicowana pod względem pochodzenia, warto tutaj chociażby wspomnieć, że w Londynie żyje obecnie jedna z największym populacji polskich Romów ${ }^{35}$.

Zmiany mniej dalekosiężne dotyczą warunków prawno-politycznych po wystąpieniu Wielkiej Brytanii z UE. Tutaj doświadczenie uczy, że należy się spodziewać pojawienia się „podziemia” imigracyjnego oraz dyskryminujących efektów wprowadzenia nowych regulacji pod postacią ograniczonego dostępu do praw socjalnych i obywatelskich, czyli de facto „produkcji” obywateli gorszej kategorii. Czynniki te nieproporcjonalnie uderzą w grupy mniej uprzywilejowane, o mniejszym kapitale kulturowym i politycznym. Szczególną uwagą powinni zostać objęci ludzie o niskich dochodach lub bezdomni, którzy nie poradzili

${ }^{34}$ Zbieraniem publikacji naukowych na ten temat zajmuje się prof. Anne White z UCL: https://www.ucl.ac.uk/ssees/people/anne-white/ssees/research/polish-migration [dostęp: 30 grudnia 2019 r.].

35 K. Fiałkowska, M.P. Garapich, E. Mirga-Wójtowicz, Roma Migrations - Transnationalism and Identity, op. cit. 
sobie na brytyjskim rynku pracy. To oni są i będą ofiarami wrogiej brytyjskiej polityki imigracyjnej, która po brexicie najprawdopodobniej wprowadzi jeszcze większe restrykcje.

Pod względem integracji - zarówno w sensie społecznym, ekonomicznym, jak i politycznym - społeczności polskie wydają się zakorzeniać bez większych problemów i systemowych perturbacji wyróżniających tę mniejszość na tle innych. Co istotne, społeczeństwo brytyjskie wydaje się już przyzwyczajone do widoku polskich sklepów, polskich sąsiadów czy współpracowników na różnym szczeblu. Rzecz jasna, wynik głosowania w referendum w 2016 r. miał sporo wspólnego z wolnym przepływem siły roboczej, a dla wielu Anglików nieprzyzwyczajonych do imigrantów, szczególnie na prowincji (która właśnie głosowała za brexitem), polscy migranci byli twarzą Unii i globalizacji, która ich ominęła. Sytuacja ta związana też była zapewne z małą obecnością Polaków w politycznej debacie w charakterze rozmówców, a nie tylko przedmiotów debaty. Nadal, zwłaszcza na szczeblu lokalnym, mało jest polityków polskiego pochodzenia, którzy byliby w stanie wnieść coś pożytecznego w tym aspekcie. Pozostaje mieć nadzieję, że będzie się to powoli zmieniać na lepsze.

\section{Bibliografia oraz wybrane monografie i publikacje dotyczące Polaków w poszczególnych miejscowościach w Zjednoczonym Królestwie}

Bielewska A., Changing Polish Identities. Post-War and Post-Accession Polish Migrants, Peter Lang AG, Internationaler Verlag, Szwajcaria 2012.

Eade J., Drinkwater S., Garapich M., Class and Ethnicity. Polish Migrants in London, University of Surrey, Guilford 2006.

Drinkwater S., Migration and integration into the UK Labour Market, IMISCOE Spring Conference Warsaw, March 2018.

Drozdowicz B., The impact of brexit on inclusion and integration of Poles in the UK [w:] Brexit and Polonia: Challenges facing the Polish Community during the process of Britain leaving the European Union, ed. M. Fleming, PUNO PRESS, 2018.

Duda-Mikulin E., EU migrant workers, brexit and precarity. Polish women's perspectives from inside the UK, Policy Press, Bristol 2019.

Dunin-Wąsowicz R., Garapich M., Zaangażowanie Polaków w brytyjskie związki zawodowe [w:] Solidarność w działaniu. Prawa pracownicze, udział $w$ dialogu społecznym oraz uzwiązkowienie Polaków w Wielkiej Brytanii, red. D. Potkańska, D. Owczarek, Instytut Spraw Publicznych, Warszawa 2015.

Fiń A. i in., Polityka polonijna w ocenie jej wykonawców i adresatów, Instytut Zachodni, Poznań 2013.

Garapich M., The Migration Industry and Civil Society: Polish Immigrants in the United Kingdom Before and After EU Enlargement, „Journal of Ethnic and Migration Studies" 2008, No 34(5). 
Garapich M., Polska kultura migracyjna po 2004: Między zmiana a tradycją [w:] Współczesne polskie migracje: strategie - skutki społeczne - reakcja państwa, red. M. Lesińska, M. Okólski, Wydawnictwo Uniwersytetu Warszawskiego, Warszawa 2013.

Garapich M., Między apatia a aktywnościa - partycypacja polityczna migrantów z Polski $w$ Wielkiej Brytanii [w:] Nic o nas bez nas. Partycypacja obywatelska, red. J. Kucharczyk, Instytut Spraw Publicznych, Warszawa 2013.

Garapich M., Breaking borders, changing structures: transnationalism of migrants from Poland as anti-state resistance, „Social Identities. Journal for the Study of Race, Nation and Culture" 2016, Vol. 22, No 1.

Grabowska I., Garapich M.P., Jazwinska E., Radziwinowicz A., Migrants as Agents of Change. Social remittances in an enlarged European Union, Palgrave Macmillan, London 2017.

Fomina J., Frelak J., Wizerunek Polski i Polaków w Wielkiej Brytanii, Instytut Spraw Publicznych, Warszawa 2011.

Fiałkowska K., Garapich M.P., Mirga-Wójtowicz E., Roma Migrations - Transnationalism and Identity in Anthropological Perspective, „Ethnologia Polona” 2019, Vol. 40.

Fleming M., Brexit and Polonia: Challenges facing the Polish Community during the process of Britain leaving the European Union, PUNO PRESS, 2018.

Grzymała-Moszczyńska H., Hay D., Krotofil J., Between universalism and ethnic particularism: Polish migrants to the United Kingdom; perspective from the psychology of religion, „Studia Migracyjne - Przegląd Polonijny” 2011, nr 37(1).

Irek M., Travelling with the Argonauts: Informal Networks Seen without a Vertical Lens Berghahn, Oxford 2018.

Kempny M., Polish Migrants in Belfast: border crossing and identity construction,

Cambridge Scholars Press, Newcastle upon Tyne 2010.

Komitet Badań nad Migracjami PAN, Społeczne skutki poakcesyjnych migracji ludności Polski, PAN, Warszawa 2014.

Krotofil J., Religion, Migration and the Dialogical Self: New Application of Personal Position Repertoire Method, „Journal of Constructivist Psychology” w druku.

Krotofil J., 'If I am to be a Muslim, I have to be a good one'. Polish migrant women embracing Islam and reconstructing identity in dialogue with self and others [w]: Muslims in Poland and Eastern Europe. Widening the European Discourse on Islam, ed. K. Górak-Sosnowska, University of Warsaw, Warszawa 2011.

Nic o nas bez nas. Partycypacja obywatelska Polaków w Wielkiej Brytanii, red. J. Kucharczyk, Instytut Spraw Publicznych, Warszawa 2013.

Nowosielski M., Zaangażowanie Polaków mieszkających za granica w działalność organizacji polonijnych, „Kultura i Edukacja” 2014, nr 1(101).

Pustułka P., Pomijani multi uczestnicy. Polacy w inicjatywach nieformalnych $w$ Wielkiej Brytanii [w:] Nic o nas bez nas. Partycypacja obywatelska Polaków w Wielkiej Brytanii, red. J. Kucharczyk, Instytut Spraw Publicznych, Warszawa 2013.

Rabikowska M., Burrell K., The material worlds of recent Polish migrants: Transnationalism, Food, Shops and Home [w:] Polish Migration to the UK in the 'New' European Union: After 2004, ed. K. Burrell, Ashgate, Aldershot 2009. 
Rabikowska M., Negotiation of normality and identity among migrants from Eastern Europe to the United Kingdom after 2004, „Social Identities. Journal for the Study of Race, Nation and Culture" 2010, Vol. 16, No 3.

Ryan L., 'Becoming Polish in London: negotiating ethnicity through migration', „Social Identities. Journal for the Study of Race, Nation and Culture" 2010, Vol. 16, No 3.

Ryan L., Sales R., Tilki M., Siara B., Family Strategies and Transnational Migration: Recent Polish Migrants in London, „Journal of Ethnic and Migration Studies” 2009, No 35(1). Svasek M., 'Shared history? Polish migrant experiences and the politics of display in Northern Ireland' [w:] Polish Migration to the UK in the 'New' European Union, ed. K. Burrell, Ashgate, Aldershot 2009.

White A., Polish families and Migration in Poland since EU Accession, Policy Press, Bristol 2011. 